\title{
Collective Guilt Makes Conflicting Parties More Collaborative: Quasi-experimental Study of the Israeli-Palestinian Conflict
}

\author{
Inna Solomatina, Ivars Austers \\ University of Latvia, Riga, Latvia
}

\begin{abstract}
The objective of the study was to investigate the impact of collective guilt on preferences towards resolutions in the Israeli-Palestinian conflict. The study was conducted in four different countries: Israel (proximate in-group implying a higher degree of identification with Israel) and the Baltic countries of Latvia, Lithuania, and Estonia (distal in-group implying a weaker identification with Israel). The participants were 240 persons representing the general Jewish population of Israel and the Baltic countries. This research was the attempt to employ both the experimental and quasi-experimental methods to examine the role of collective guilt on preferences for Israeli-Palestinian conflict resolution strategies. In general, the study showed that collective guilt was facilitated by experimental manipulation. The greater collective guilt was provoked in groups with Israeli guilt and ambiguous information. Baltic respondents were more ready to accommodate and collaborate than Israeli respondents. In general, collective guilt and age facilitated a collaborating strategy, but the perceived legitimacy of group relationships and glorification predicted a competing strategy. The more one felt collective guilt, the greater the readiness was to cooperate. The stronger the identification with Jewish people, the less the readiness was to collaborate with the out-group.
\end{abstract}

Keywords: collective guilt, Israeli-Palestinian conflict, conflict resolution, in-group identification, social identity theory

\section{Introduction}

\section{Social Identity and Collective Guilt}

It is almost impossible to imagine our lives without considering the relationships we have with the people who are important to us: family, friends, colleagues, neighbors, etc.. All these people form groups which influence our thoughts, feelings, and behaviours. We may derive our emotional reactions to others from the group with which we identify (Tajfel \& Turner, 1979). Immoral activities of an in-group may be perceived as harmful to one's group identity since the human identity is based on group belongingness and the desire to think of one's group positively which is often related to group exonerating strategies (Wohl, Branscombe, \& Klar, 2006). However, when for some reasons this is not possible, people may feel collective guilt with a strength equivalent to the threat of in-group activities in the past, to present moral standards. People may have difficulties in simultaneously avoiding self-categorization as a member of a certain group and denying their collective responsibility. If such a strategy does not work, people start to feel collective guilt in relation to the 
group (Branscombe \& Doosje, 2004). Despite the fact that one may not have been involved in harming certain group members, pure associations with the guilty group may elicit such emotions as collective guilt (Wohl \& Branscombe, 2005). From the moment a person starts to identify oneself with a group, he/she is less ready for confrontations with negative episodes involving the in-group. When a person feels less connected to the group, he/she is ready to recognize the negative experience. People with low identification feel relatively stronger collective guilt (Doosje, Branscombe, Spears, \& Manstead, 1998) and dispositional attribution to the behaviour of their group (Doosje \& Branscombe, 2003). According to these findings, people with lower identification are more supportive of the reparation policy (Doosje, Branscombe, Spears, \& Manstead, 1998). People with a higher degree of identification feel superiority; therefore, they feel less collective guilt and do more external attributions (Doosje \& Branscombe, 2003), which result in lower involvement with reparation actions (Doosje, Branscombe, Spears, \& Manstead, 1998).

Research at the end of the 20th century and the beginning of the 21 st century revealed contradictory results about the relationships between identification and collective guilt. For example, Doosje et al. (1998) first found negative connections, then a positive one, or did not find any connections at all (Branscombe, Slugoski, \& Kappen, 2004). Under conditions of ambiguous information, people with low identification felt more collective guilt than did people with high identification (Schmitt, Branscombe, \& Brehm, 2004). On the one hand, people with high identification must have a higher moral responsibility for activities of the in-group, which may mean that collective guilt can be positively related to identification. On the other hand, on the basis of social identity theory, it has been established that people who identify more with the in-group will also be more motivated to maintain positive social identity; hence, they will experience a higher degree of confrontation with negative information about the in-group and will try to find an alternative interpretation of it. According to this line of reasoning, group identification facilitates the perceived legitimacy of intergroup relationship; hence, less guilt will be experienced regarding the group's action. By summarizing both of these approaches, identification may simultaneously be related both positively and negatively to collective guilt; this issue is still under discussion. A recent study found a non-linear effect of identification on collective guilt (Klein, Licata, \& Pierucci, 2011). Respectively, it was discovered that an inverted U relationship exists between group identification and collective guilt-The strongest feelings of collective guilt were found for those with an average degree of identification. A negative correlation has been found between the degree of identification and recognition of the severity of harm, as well as a positive correlation between the degree of identification and the perceived legitimacy of intergroup actions (Klein, Licata, \& Pierucci, 2011). In addition, a negative effect of identification on reparation support, as well as a positive correlation between collective guilt and reparation support has been found. This relationship indicates two different processes: collective guilt serves as a function of social identity, where the social identity facilitates the feeling of guilt, while collective guilt endangers social identity; thus, people with higher identification use defensive reactions (Klein, Licata, \& Pierucci, 2011).

In order to solve the identification-guilt paradox, Roccas, Sagiv, Schwartz, Halevy, and Eidelson (2008) offer a new multi-dimensional model of group identification. Roccas, Klar, and Liviatan (2006) proposed looking at identification as two dimensions: attachment (a combination of importance and commitment) and glorification mode (a combination of superiority and deference). The more people glorify their group, the smaller is the collective guilt which they feel. The attachment mode is positively related to collective guilt in the case where the glorification dimension is being controlled, which means that glorification reduces the effect 
of attachment identification to collective guilt in general.

National and other social groups have their own history. Reminding a group about its history can affect current emotional reactions considerably. When people think about different aspects of their group's history, they may feel collective pride; in turn, there are some aspects of group history which can cause collective guilt and a wish to minimize the harm. Such emotional reactions are increased, not by personal involvement in these situations, but by a categorization of the personal I as a part of the group. "Collective guilt is a group-based guilt", which could be conceptualized as guilt that is experienced as a consequence of belonging to a group that has done something that is perceived as illegitimate (Doosje et al., 2006, p. 326). In general, four main processes in the course of the emergence of collective guilt are under discussion: self-categorization with a group that has harmed another group, an acceptance of group responsibility for the harm, recognition of illegitimate activity, and harm reparation efforts (Wohl et al., 2006). People self-categorize as members of a group, which has caused harm to another group. Group members take group responsibility for activities which caused harm to another group. Group members recognize the illegitimacy of the group activities. The size of the collective guilt will depend on the harm reparation "expenses" or costs of such efforts. From the perspective of social identity theory, an increase in the significance of the group enlarges the possibility that the individual will experience emotions coming from belonging to the group (Tajfel \& Turner, 1979). People are protective of their in-group image: in-group members may try to minimize or deny the responsibility of their group for the harm, or they can admit it as legitimate (Wohl et al., 2006). Another possibility for reducing collective guilt is the mechanism of exonerating cognitions (Roccas, Klar, \& Liviatan, 2004).

Negative information about the in-group's past endangers group morality; consequently, people with high identification will do everything to deny such information. Based on the information source, people make a decision about the credibility of the information. Doosje et al. (2006) investigated the effect of information sources and national identification on collective guilt. They found that in cases when the information was presented by an out-group, participants felt less collective guilt; whereas, when the information was presented by the in-group, participants had difficulties in denying it, which resulted in higher collective guilt. The linking of this cognition with the level of identification shows that with high identification, people are more affected when the source is the in-group and consequently feel more collective guilt.

\section{The Israel-Palestine Conflict}

The Israel-Palestine conflict has been widely researched in the context of different factors: collective emotions, matters of identification, socio-demographic variables, etc.. Most studies on resolutions of the Israel-Palestine conflict are correlative; and only a small part is composed of research of an experimental design (Maoz, 2009; Wohl \& Branscombe, 2008). It has been found that resistance to compromise is best predicted by social confidence about the zero-sum nature of the conflict and the perceived threat from the Palestinian side. Meanwhile, readiness for compromise is positively related to sympathy for the Palestinians, which, in turn, is not connected to fear of them (Maoz \& McCauley, 2005). Another explanation is linked to the attribution of illegitimacy to the Palestinians. Halperin, Bar-Tal, Nets-Zehngut, and Drori (2008) found that attribution of illegitimacy to the Palestinians is negatively related to hope and optimism in respect to conflict resolution. Dehumanization of the Palestinians facilitates aggressive activities by the Israelis (Maoz \& 
McCauley, 2008). A large part of the research is devoted to the influence of the in-group victim role on forms of conflict resolution. Research of different groups discloses the following: Trust of the in-group victim role is connected to low receptiveness to new information about the conflict and low support for compromise (Bar-Tal, Chernyak-Hai, Schori, \& Gundar, 2009). People, who believed that Israel bore the role of a victim, believed more in only the Jewish people having the right to Israel's territories, were more supportive of dehumanizing ideas about Arabs and Palestinians; they ascribed the guilt for the length and failures of the conflict to the out-group; they felt a deeper hate of the out-group and, consequently, gave less support to compromise. People who were more accepting of the role of victim felt less guilt for the causes, were less ready to assume group liability and were less ready to compensate the harm caused to Palestinians. In addition, such people applied exonerating cognitions (Bar-Tal et al., 2009). Trust in the vulnerability of the in-group facilitated aggressive behaviour and less searching for compromises (Maoz \& Eidelson, 2007). A recent study disclosed that trust in the in-group victim role is related to a wish to offend Palestinians and negatively related with collective guilt (Schori, Klar, \& Roccas, 2009).

Some of the studies have been devoted to the effect of emotions on conflict resolution. A recent study by Halperin (2011) reveals that fear facilitates destructive methods of conflict resolution. People with stronger fear emotions, were less ready to support a compromising strategy because of the lack of security. Israeli respondents experiencing hate gave much stronger support to activities related to aggression by Israel and weaker support for compromise (Halperin, 2008).

The present study was designed in a way that it integrated both experimental manipulations of guilt, as well as quasi-experimental differences in identification - Our participants were from Israel (proximate in-group implying a higher degree of identification with Israel) and Baltic countries (distal in-group implying a weaker identification with Israel). "Diaspora" Jews probably identify themselves as Jews but not as "Israelis". In addition to differences in level and mode of identification with Israel, there are also real differences in terms both of responsibility for and consequences of particular resolution strategies. The proximate in-group (Israeli Jews) has much more direct influence on past, present and future policy-making than the distal in-group (Baltic Jews). That is also the reason why we suggested, that Israeli Jews would be more risk-averse in their choices and employ defensive coping strategies when they would be adversely affected in ways that the Baltic Jews would not. We expected to determine the impact of collective guilt on preferences for Israeli-Palestinian conflict resolution strategies. We tested two hypotheses:

(1) That collective guilt would facilitate a readiness to support a collaborative strategy of conflict resolution;

(2) Baltic Jews (distal in-group) would identify with Israel less than the Israelis Jews (proximate in-group) would; as a result, they would feel a stronger collective guilt and would be ready to choose a collaborative strategy to a greater extent.

\section{Method}

The study was a 2 (country) $\times 4$ (collective guilt manipulation) quasi-experiment. The country (expected to manifest a high and low identification of the participants with Israel) served as a quasi-experimental factor. Collective guilt (high/low) was manipulated by offering different facts about the Israel-Palestine conflict to participants to read that indicate the guilt of one or other party. To determine the level of identification and collective guilt, respondents filled in two questionnaires. In addition to collective guilt, the readiness to accept 
group responsibility, the perceived legitimacy of the group relationship, and the exonerating cognitions were measured. Conflict resolution strategy (the dependent variable) was measured by a list of feasible solutions to the Israel-Palestine conflict. In addition, questions were asked about readiness for social contact with the out-group (Palestinians).

The quasi-experiment involved participants from four countries: Latvia, Lithuania, Estonia, and Israel. Jewish people with their own attitudes and preferences with respect to the Israel-Palestine conflict live in each of these countries. Studies with a similar scope of interest were performed mainly in one country only, in Israel. We treated the study sample as a set of two sub-samples: one from the Baltic countries (Latvia, Lithuania, and Estonia) and another from Israel. The participants were recruited from schools, universities, and Jewish communities. The quasi-experiment was completely computerized.

\section{Participants}

There were 240 Jewish respondents of both genders in the age range from 15 to 36 years with a mean age of $22.8(S D=5.06)$ taking part in the quasi-experiment. The mean age of Baltic participants was $22.2(S D=$ $4.72)$, and the mean age of Israel respondents was $23.3(S D=5.34)$. There was no difference in age between the respondents $t_{(238)}=-1.67, p>0.05$. Each sub-sample contained 69 women and $51 \mathrm{men}$. Six participants from the Baltic countries described themselves as atheists, and 114 - as followers of Judaism, while four participants in Israel described themselves as atheists, and 116-as followers of Judaism. The results of the $\chi^{2}$ test, showed no differences in the religion between the subsamples $\left(_{(1, N=240)}^{2}=0.42, p>0.05\right)$. However, there were differences in importance attached to religion in Israel $(M=3.40, S D=1.49)$ vs. the Baltic countries $(M=2.97$, $S D=1.18), t_{(238)}=-2.50, p<0.05$. These results suggest that Israeli respondents are more attached to religion than Baltic respondents.

An independent-sample $t$-test was conducted to compare gender differences. There were some gender differences stated; respectively, there were statistically significant differences between men $(M=2.54, S D=$ $1.30)$ and women $(M=2.94, S D=1.40)$ in collective guilt $t_{(238)}=2.30, p<0.05$ and a statistically significant difference between men $(M=2.96, S D=1.39)$ and women $(M=3.35, S D=1.32)$ in the importance of religion $t_{(238)}=2.20, p<0.05$. In general, women felt collective guilt more and attached more importance to religion.

In each sub-sample, four randomized groups were formed. Each group had a different manipulation of guilt: Israeli guilt, Palestinian guilt, ambiguous guilt, and neutral information. Respectively, the first three groups had a collective guilt manipulation while the fourth served as a control group. Each experimental group consisted of 30 persons.

\section{Measurements and Procedure}

Two items of identification with Israel ("Israel is important state for me", $\alpha=0.75$ ) and two items of Jewish people's identification ("Jewish people are an important group for me", $\alpha=0.85$ ), together four statements from the "Identification scale with the Dutch" (Doosje et al., 2006) were used in the current research. Four modes of attachment ("I am strongly committed to Israel", $\alpha=0.79$ ) and four modes of glorification ("Other nations can learn a lot from Israel", $\alpha=0.74$ ), together eight statements from the "Measure of identification with Israel” (Roccas et al., 2006) were used. Respectively, 12 statements were established in total for the measurement of identification with the in-group. Agreements with the statements ranged from 1 ("Disagree completely") to 7 ("Completely agree").

The research lasted four months (from January to April). Two assistants organized the quasi-experiment in 
Israel. The research was performed in two languages: Russian (in Latvia, Lithuania, and Estonia) and Hebrew in Israel. To ensure the comparability of Russian and Hebrew experiment versions, pilot researches were conducted; no differences were found in translations. The Russian language was native language for Baltic Jews, the Hebrew was native language for Israeli Jews. First, the quasi-experiment was carried out in the Baltic countries; afterwards the Israeli sample was formed by matching age and gender. The quasi-experiment was completely computerized. The quasi-experiment was performed in a frontal mode; respectively, 2-7 people participated simultaneously. Each participant sat at computer; the process had no time limit. In the first stage of the study, the participants were asked to rate their level of identification. After that, each participant was randomly provided some experimental manipulation (reading facts about Israel's guilt, Palestinian guilt, ambiguous guilt or neutral information). After this, a manipulation check was provided: The respondents filled in the statements on collective guilt, in-group responsibility, perceived legitimacy of the group relationship and exonerating cognitions. And finally respondents rated 14 different conflict resolutions and readiness for social contact with the out-group. At the end of the quasi-experiment, participants were asked to answer questions about their gender, age, city of residence, occupation, study program (in the case of students), religious adherence, and the importance of religion to them. The participants were also provided with a debriefing at the end of the research.

\section{Dependent Variables}

The degree to which collective guilt was accepted by participants was assessed by four statements ("I feel guilty when I think about Israel's policy towards Palestinians", $\alpha=0.87$ ). These items were used from "Collective guilt measurement" (Wohl \& Branscombe, 2008). In addition, two statements about in-group responsibility ("Israel assumes the key responsibility for consequences from the conflict with Palestinians", $\alpha=$ 0.86) were used (Wohl \& Branscombe, 2008). Two additional statements about the perceived legitimacy of group relationship ("Palestinian terrorism made Israel defend itself using its armed forces", $\alpha=0.51$ ) were measured (Wohl \& Branscombe, 2008). We also measured exonerating cognitions by two statements ("I think that information reflected in the previous slide is too negative in respect to Israel", $\alpha=0.83$ ) (Roccas et al., 2006). Ratings were made from 1 ("Disagree completely") to 7 ("Completely agree").

For an evaluation of the conflict resolution strategies, participants assessed every resolution from a given list on a scale from -3 ("Completely against") to 3 ("Support completely"). The list consisted of 14 possible resolutions to the Israeli-Palestinian conflict. Four resolutions measured collaboration ("Organize peace negotiations", $\alpha=0.76$ ), three measured competition ("Jerusalem and other places belong only to Israel", $\alpha=$ 0.73), three measured avoidance ("Develop relationships with other countries and not deal with Israel-Palestinian conflict", $\alpha=0.61$ ), and four measured accommodation ("Israel provides some part of Jerusalem to Palestine", $\alpha=0.74$ ).

A Bogardus-type scale was used to measure readiness for out-group social contact. Participants had to respectively assess the level of their readiness for involvement in contact with Palestinians. Respondents were asked: "How willing would you be to have each of the following contacts with a Palestinian". Respondents replied on a 5-point scale anchored by 1 ("Not at all willing") and 5 ("Definitely willing") (Y. Bar-Tal, D. Bar-Tal, \& Cohen-Hendeles, 2006; Sagiv \& Schwartz, 1995). Seven items described different types of contact, for example, "living in the same neighborhood". Responses to the seven items were averaged as an overall index of readiness for contact. The internal reliability of this index was 0.92 . 


\section{Results}

We expected to determine the impact of collective guilt on preferences for Israeli-Palestinian conflict resolution strategies. Two hypotheses were assessed during the research:

(1) That collective guilt would facilitate a readiness to support a collaborative strategy of conflict resolution;

(2) Baltic Jews (distal in-group) would identify with Israel less than the Israelis Jews (proximate in-group) would; as a result, they would feel a stronger collective guilt and would be ready to choose a collaborative strategy to a greater extent.

\section{Impact of Independent Variables}

An independent-sample $t$-test was conducted to compare identification with Israel. There was a significant difference in the score of identification with Israel between Baltic $(M=5.24, S D=1.26)$ and Israeli respondents $(M=6.50, S D=0.70), t_{(238)}=-9.65, p<0.001$. There was a significant difference in the score of the identification attachment mode between Baltic $(M=4.93, S D=1.14)$ and Israeli respondents $(M=6.20, S D$ $=0.84), t_{(238)}=-9.86, p<0.001$. Respectively, Israeli respondents had a higher identification with the country as well as a higher attachment to Israel.

In order to test experimental manipulation, we performed a 2 (country) $\times 4$ (type of collective guilt manipulation) ANOVA on the measure of collective guilt, in-group responsibility, exonerating cognitions and in-group legitimacy. Irrespective of the country $(F<1$, n.s. $)$, there were differences between experimental groups in collective guilt, $F_{(3,232)}=21.95, p<0.001$, and a post-hoc analysis Bonferroni test $(p$ $<0.05)$ revealed that a higher collective guilt was raised in the Israeli guilt group and in the group with ambiguous information (see Table 1 for the results). There were statistically significant differences between experimental groups in the in-group responsibility measurement $F_{(3,232)}=8.94, p<0.001$, and a post-hoc analysis Bonferroni test $(p<0.05)$ revealed that a higher in-group responsibility was raised in the Israeli guilt group and in the group with ambiguous information (see Table 1 for the results). There were also differences between countries as well $\left(F_{(1,232)}=7.39, p<0.01\right)$. Baltic respondents $(M=2.47, S D=1.26)$ were, in general, more ready to assign responsibility to Israel than Israel respondents were $(M=2.02, S D=1.40)$. There were also differences between experimental groups in the measurement of the exonerating cognitions $F_{(3,232)}=46.09, p<0.001$, and a post-hoc analysis Bonferroni test $(p<0.05)$ revealed that higher exonerating cognitions were raised in the Israeli guilt group and in the group with ambiguous information (see Table 1 for the results). The ANOVA also showed that experimental manipulation or the country, or interaction of the factors had no effects on in-group legitimacy $(F<1$, n.s.). No interaction effects were found to be significant.

\section{Tests of Hypotheses}

In order to test the hypotheses we regressed conflict resolution strategies one by one on a set of predictor variables: experimental manipulation (coded as a dummy variable — respective experimental manipulation was coded 1 against the control group coded as 0), identification with Israel, identification with Jewish people, modes of attachment and glorification, collective guilt, in-group responsibility, in-group legitimacy, exonerating cognitions, gender, age, importance of religion, and country of the participants. Results of all the regressions are presented in Table 2. 
Table 1

Descriptive Statistics of Variables of the Study

\begin{tabular}{|c|c|c|c|c|c|c|c|c|c|}
\hline & & \multicolumn{2}{|c|}{ Israeli guilt } & \multicolumn{2}{|c|}{ Palestinian guilt } & \multicolumn{2}{|c|}{ Ambiguous information } & \multicolumn{2}{|c|}{ Control group } \\
\hline & & Baltic M(SD) & Israel M(SD) & Baltic M(SD) & Israel M(SD) & Baltic M(SD) & Israel M(SD) & Baltic M(SD) & Israel M(SD) \\
\hline \multirow{4}{*}{ Identification } & $\begin{array}{l}\text { Identification } \\
\text { with } \\
\text { Israel (2) }\end{array}$ & $5.68(1.23)^{* * *}$ & $6.63(0.64)^{* * * *}$ & $4.92(1.47)^{* * * *}$ & $6.53(0.63)^{* * *}$ & $5.08(1.01)^{* * * *}$ & $6.27(0.90)^{* * *}$ & $5.27(1.21)^{* * *}$ & $6.58(0.56)^{* * *}$ \\
\hline & $\begin{array}{l}\text { Identification } \\
\text { with } \\
\text { Jewish people (2) }\end{array}$ & $6.38(1.06)$ & $6.10(1.12)$ & $5.82(1.48)$ & $5.92(1.58)$ & $6.07(1.12)$ & $5.62(1.52)$ & $5.58(1.73)$ & $8.28(1.28)$ \\
\hline & $\begin{array}{l}\text { Mode of } \\
\text { attachment (4) }\end{array}$ & $4.95(1.10)^{* * *}$ & $6.30(0.74)^{* * * *}$ & $4.91(1.31)^{* * * *}$ & $6.23(0.90)^{* * *}$ & $4.97(0.91)^{* * *}$ & $6.00(1.01)^{* * * *}$ & $4.89(1.25)^{* * *}$ & $6.29(0.70)^{* * *}$ \\
\hline & $\begin{array}{l}\text { Mode of } \\
\text { glorification (4) }\end{array}$ & $5.31(1.05)$ & $5.07(1.30)$ & $5.30(1.16)$ & $5.26(0.87)$ & $5.16(0.88)$ & $4.71(1.19)$ & $5.54(0.98)$ & $5.32(1.13)$ \\
\hline \multirow{4}{*}{$\begin{array}{l}\text { Experimental } \\
\text { manipulation }\end{array}$} & $\begin{array}{l}\text { Collective guilt } \\
\text { (4) }\end{array}$ & $3.52(1.61)^{\mathrm{a}}$ & $3.57(1.53)^{\mathrm{a}}$ & $2.16(0.63)^{\mathrm{b}}$ & $2.39(1.04)^{\mathrm{b}}$ & $3.22(1.43)^{\mathrm{a}}$ & $3.29(1.55)^{\mathrm{a}}$ & $1.95(0.65)^{\mathrm{b}}$ & $2.08(0.86)^{\mathrm{b}}$ \\
\hline & $\begin{array}{l}\text { In-group } \\
\text { responsibility (2) }\end{array}$ & $3.15(1.42)^{*, a}$ & $2.18(1.63)^{*}$ & $2.12(0.88)^{\mathrm{c}}$ & $1.95(1.40)$ & $2.87(1.43)^{\mathrm{a}, \mathrm{c}}$ & $2.38(1.56)$ & $1.73(0.60)^{\mathrm{b}}$ & $1.57(0.81)$ \\
\hline & $\begin{array}{l}\text { In-group } \\
\text { legitimacy (2) }\end{array}$ & $5.80(0.96)$ & $5.57(1.32)$ & $5.18(1.43)^{* *}$ & $6.07(1.03)^{* * *}$ & $5.45(1.08)$ & $5.40(1.26)$ & $5.48(1.21)$ & $5.53(1.20)$ \\
\hline & $\begin{array}{l}\text { Exonerating } \\
\text { cognitions (2) }\end{array}$ & $5.17(1.44)^{\mathrm{a}}$ & $5.42(1.34)^{\mathrm{a}}$ & $3.69(1.56)^{b}$ & $3.32(2.14)^{b}$ & $4.30(1.01)^{\mathrm{a}, \mathrm{b}}$ & $4.23(1.94)^{\mathrm{a}, \mathrm{b}}$ & $2.20(1.18)^{\mathrm{c}}$ & $1.92(1.52)^{\mathrm{c}}$ \\
\hline \multirow{4}{*}{$\begin{array}{l}\text { Conflict } \\
\text { resolutions }\end{array}$} & Collaborating (4) & $1.31(1.08)^{* * * *}$ & $-0.11(1.29)^{* * *}$ & $1.10(1.08)^{* * * *}$ & $0.04(1.31)^{* * * *}$ & $0.94(1.17)^{* * *}$ & $-0.02(1.39)^{* * *}$ & $1.13(1.25)^{* *}$ & $0.20(1.35)^{* *}$ \\
\hline & $\begin{array}{l}\text { Accommodating } \\
\text { (4) }\end{array}$ & $-0.71(0.98)^{* * *}$ & $-1.56(1.34)^{* *}$ & $-0.86(1.09)^{*}$ & $-1.63(1.33)^{*}$ & $-1.00(1.15)$ & $-1.21(1.71)$ & $-1.03(1.22)^{* * *}$ & $-2.05(1.19)^{* * *}$ \\
\hline & Competing (3) & $-0.53(1.33)$ & $-0.32(1.85)$ & $-0.09(1.48)$ & $-0.34(1.73)$ & $-0.10(1.54)$ & $-0.42(1.85)$ & $0.01(1.51)$ & $-0.24(1.56)$ \\
\hline & Avoiding (3) & $0.06(1.22)^{*}$ & $-0.81(1.47)^{*, a}$ & $-0.19(1.36)$ & $-0.20(1.44)^{\mathrm{a}, \mathrm{b}}$ & $0.11(1.31)$ & $0.18(1.12)^{b}$ & $0.13(1.30)$ & $-0.19(1.22)^{a, b}$ \\
\hline $\begin{array}{l}\text { Readiness for } \\
\text { social } \\
\text { contact with } \\
\text { out-group }\end{array}$ & 7 statements & $2.55(0.93)$ & $2.42(1.10)$ & $2.35(0.79)$ & $2.31(1.03)$ & $2.53(1.02)$ & $2.15(1.11)$ & $2.63(0.70)$ & $2.30(1.06)$ \\
\hline
\end{tabular}

Notes. " $(p<0.05),{ }^{* *}(p<0.01),{ }^{* * * *}(p<0.001) ;{ }^{\text {a, b,c }}$ Means that share the same superscripts does not differ at $p>0.05$ in compliance with Bonferroni Post-Hoc test results.

Table 2

Regression Predicting Conflict Resolutions and Readiness for Social Contact With Out-Group

\begin{tabular}{|c|c|c|c|c|c|c|c|c|c|c|c|c|c|}
\hline \multirow{3}{*}{ Independent measures } & \multicolumn{13}{|c|}{ Dependent variables } \\
\hline & \multicolumn{3}{|c|}{ Collaborating $^{\text {a }}$} & \multicolumn{3}{|c|}{ Accommodating ${ }^{b}$} & \multicolumn{3}{|c|}{ Competing $^{\mathrm{c}}$} & Avoiding ${ }^{\mathrm{d}}$ & \multicolumn{3}{|c|}{$\begin{array}{l}\text { Readiness for social contact with } \\
\text { out-group }^{\text {e }}\end{array}$} \\
\hline & $B$ & & $\beta$ & $B$ & $S E B$ & $\beta$ & $B$ & $S E B$ & $\beta$ & $S E B$ & $B$ & $S E B$ & $\beta$ \\
\hline \multicolumn{14}{|l|}{ Identification with Israel } \\
\hline $\begin{array}{l}\text { Identification with } \\
\text { Jewish people }\end{array}$ & -0.12 & 0.06 & $-0.13^{*}$ & & & & & & & & & & \\
\hline \multicolumn{14}{|l|}{ Mode of attachment } \\
\hline Mode of glorification & & & & -0.15 & 0.08 & $-0.13^{*}$ & 0.41 & 0.09 & $0.28^{* * * *}$ & & & & \\
\hline Collective guilt & 0.23 & 0.06 & $0.23^{* * *}$ & & & & -0.22 & 0.08 & $-0.19^{* *}$ & & 0.20 & 0.05 & $0.28^{* * *}$ \\
\hline In-group responsibility & & & & 0.37 & 0.06 & $0.37^{* * *}$ & & & & & & & \\
\hline In-group legitimacy & & & & -0.17 & 0.07 & $-0.16^{* *}$ & 0.25 & 0.09 & $0.19^{* *}$ & & -0.24 & 0.05 & $-0.29^{* * * *}$ \\
\hline Exonerating cognitions & -0.10 & 0.04 & $-0.15^{*}$ & & & & & & & & & & \\
\hline \multicolumn{14}{|l|}{ Gender } \\
\hline Age & 0.03 & 0.02 & $0.13^{*}$ & & & & & & & & & & \\
\hline Importance of religion & & & & & & & & & & & -0.10 & 0.04 & $-0.15^{*}$ \\
\hline Country & -1.17 & 0.15 & $-0.43^{* * *}$ & -0.43 & 0.17 & $-0.17^{*}$ & & & & & & & \\
\hline \multicolumn{14}{|l|}{ Israeli guilt } \\
\hline \multicolumn{14}{|l|}{ Palestinian guilt } \\
\hline Ambiguous information & & & & & & & & & & & -0.27 & 0.13 & $-0.12^{*}$ \\
\hline
\end{tabular}


As we can see in the case of collaborating identification with Jewish people, exonerating cognitions predict it negatively, while collective guilt and participants' age positively. Baltic participants too were more positive towards collaborating than their Israeli counterparts. Accommodating strategy was negatively predicted by the mode of glorification and the perceived in-group legitimacy, while positively by the perceived in-group responsibility. In this case too, Baltic participants were more prone to suggest this strategy in comparison with Israeli participants. A competing strategy was negatively predicted by perceived collective guilt, but positively by the mode of glorification and the perceived in-group legitimacy. Regression of the avoiding strategy did not yield any statistically significant results. We also regressed the readiness for social contact with the out-group on the same set of variables as for the conflict resolution strategies. For this analysis we found that the perceived in-group legitimacy, importance of religion, and experimental manipulation of ambiguous information were negative predictors, while the perceived collective guilt was a positive predictor.

\section{Discussion and Conclusion}

Results of the quasi-experiment show that the hypothesis that collective guilt facilitates a readiness to support a collaborative strategy was partially confirmed. Respectively, the collective guilt predicts a collaborative strategy in general; however, the experimental manipulation of collective guilt alone did not succeed in promoting choice of a collaborative strategy. To some extent these findings are in line with other studies showing that collective guilt facilitates compensation (Sharvit, Halperin, \& Rosler, 2011) and promotes motivation for averting the harm caused by the in-group (Doosje et al., 1998). Another hypothesis "Baltic Jews (distal in-group) would identify with Israel less than the Israelis Jews (proximate in-group) would; as a result, they would feel a stronger collective guilt and would be ready to choose a collaborative strategy to a greater extent" was also partially confirmed. Respectively, Israeli Jews had a higher identification with the country of Israel as well as a higher attachment mode to Israel than Jewish people from the Baltic countries; however, participants from both countries had roughly the same level of collective guilt. Simultaneously, Baltic respondents are more supportive of a collaborative strategy than Israeli respondents are. One of the explanations is the construal level theory and its effect on social judgments (Trope \& Liberman, 2010). Negotiators located in different places are able to find a better solution than under a condition of reduced distance between them (Henderson, 2010). Respectively, the ones living near the conflict area are operating with more detailed information than are people living far away from the conflict zone; thus, finding a complete compromise might be more complicated. Consequently, Jewish people living far away from the conflict area are more tended towards negotiations with the opponents. One more explanation is that in addition to differences in level and mode of identification with Israel there are real differences between Baltic and Israeli Jews in terms both of the responsibility for and consequences of particular resolution strategies. The proximate in-group (Israeli Jews) has more direct influence on past, present and future policy-making than the distal in-group (Baltic Jews), and different implications for collective guilt could be demonstrated. It would be quite natural for Israeli Jews to be more risk-averse in their choices and employ defensive coping strategies when they would be adversely affected in ways that the Baltic Jews would not. Another explanation is related to the fact that people involved in conflict are more accepting of the role of victim (Branscombe, 2004); thus, Israeli participants are less ready for a positive solution to the problem than are Jewish people living outside the conflict area. Similar studies have disclosed that trust in the in-group victim role is related to a low receptiveness to new information about the conflict and low support for compromises (Bar-Tal et al., 2009). 
People believing in the victim role of Israel had a greater belief that Jewish people have a right to Israeli territories, were more supportive of dehumanizing ideas about Arabs and Palestinians, attributed the fault for the length of the conflict and failures to the out-group, felt stronger hate towards the out-group, and, consequently, were less supportive of compromise. This might be one of the explanations for the fact that the people in the conflict area resistant to positive collaboration.

An important finding is related to the identification measurement: Israeli Jews have a higher identification with the country of Israel as well as a higher attachment dimension to Israel than have Baltic respondents. This tendency showed up in all experimental groups. It coincides logically with the idea that people identify themselves more with the country in which they are living. This was exactly predicted in the planning of the present study. Measures of the experimental manipulations showed that the highest collective guilt was provoked in the Israeli guilt group and in the group with ambiguous information in both countries. In general, Israeli and Baltic participants feel collective guilt at the same level. Baltic participants are in general more ready to assign group responsibility to Israel than Israeli Jews. In groups where collective guilt was provoked the most (Israeli guilt group and the ambiguous information group), group responsibility's assignment was also provoked more. Nevertheless, theoretical speculation proves that the in-group can use several mechanisms to protect itself: People may not admit responsibility or declare the damage as legal (Wohl, Branscombe, \& Klar, 2006). It is possible that, when reading negative information about their in-group, Israeli participants were blaming Palestinians for their misfortune and were trying to excuse their own behaviour. Consequently, people from a group with a higher degree of identification were more resistant to admitting group responsibility, while people from a group with a lower degree of identification were more flexible in the recognition of their in-group's failures.

Higher in-group responsibility's assignment was observed in the Israeli guilt group and the ambiguous information group. Stronger exonerating cognitions are observed in the Israeli guilt group and in the ambiguous information group. Consequently, an increase in collective guilt made the admission of group responsibility more and more annoying and people began to look for exonerating strategies (Klein, Licata, \& Pierucci, 2011). This is why higher collective guilt and higher exonerating cognition scores were stated in the Israeli guilt group and in the ambiguous information group. Baltic and Israeli respondents use exonerating cognitions of approximately the same level. The in-group legitimacy parameter of the Baltic and Israel respondents was approximately at the same level in all experimental groups. It is possible that the ambiguous information reflects the most precise reality about the suffering of both parties and the mutual responsibility of both parties for the continuation of the conflict; therefore, a higher collective guilt and a lower parameter of in-group legitimacy was stated in this group.

The regression analyses showed that experimental manipulation on its own does not affect the preference for any of the four conflict strategies. At the same time, it was discovered that the country influences the accommodating and the collaborative strategy. It means that Baltic respondents were more ready for accommodation and cooperation than were Israeli respondents across all experimental groups. It coincides with findings stating that persons with a lower level of identification are ready for cooperation to a higher extent, as well as being more ready to admit group responsibility than are persons with a high degree of identification (Doosje et al., 1998). Baltic and Israeli participants supported both the competing and the avoiding strategies similarly. In general, Baltic participants were ready to support a collaborative strategy in all experimental groups to a higher extent than were Israeli respondents. In addition, the results obtained confirmed that people 
with a higher degree of identification (in this study the Israelis) are more ready to resist negative information than are people with a lower identification with the in-group (in this study the Baltic participants), and consequently, were less ready to be involved in reparation actions (Doosje et al., 1998). People tend to protect the image of their in-group- they can minimize or deny the responsibility of their group for the damage they have caused, or they can acknowledge it as legal (Wohl, Branscombe, \& Klar, 2006).

The quasi-experiment disclosed that in-group responsibility positively predicts the accommodating strategy. It means the following: The more respondents are ready to assign responsibility to in-group, the more they are ready to accommodate in the conflict. Meanwhile, in-group legitimacy, the country, and the glorification dimension predict a readiness to accommodate negatively. Namely, the more people support in-group legitimacy, the less they are ready to accommodate. Israeli respondents are, in general, less ready for accommodation. Collective guilt predicts a readiness for competing negatively, which in turn means that in the case of a higher collective guilt, there will be less support for a strategy of competing. The glorification strategy and in-group legitimacy predicted a competing strategy positively. It means the following: The higher one scores on the glorification dimension, and the more one supports in-group legitimacy, the more he/she will be ready to use the strategy of competition. Previous studies have found that the glorification dimension reduces the demand for justice through moral recovery; thus, the glorification dimension does not permit acceptance of critical information about in-group behaviour (Leidner, Castano, Zaiser, \& Giner-Sorolla, 2010); consequently, it may lead to destructive resolutions of the conflict. This research also supported the fact, that different identification modes could predict conflict resolution strategies. It is another substantiation for the multidimensional concept of identification (Roccas et al., 2008), which can be more efficiently observed by the application of several dimensions. Strong identification with the in-group increases hostility to the out-group and reduces the ability of in-group participants to see the demands of the other party as legitimate (Ashforth \& Mael, 1989).

Collective guilt and age predict support for a collaborative strategy positively. It means that, by age, people are tended more towards cooperation; in addition, the stronger the collective guilt, the more people are ready to support a collaborative strategy. Meanwhile, the country, the exonerating cognitions, and the identification with Jewish people predict a collaborative strategy negatively. In general, Baltic respondents support cooperation more; and the more respondents exonerated behaviour and the higher the identification with Jewish people, the less the participants were cooperation-oriented. It coincides with other studies, which have found that exonerating cognitions are related to the overall tendency to minimize the consequences of harm created by the in-group behaviour (Roccas et al., 2004).

Collective guilt was positively related to the readiness to engage in social contacts with Palestinians, which means that the more the collective guilt is admitted, the more ready people will be to engage in contacts with the out-group. The in-group legitimacy and the importance of religion negatively predicted the involvement in social contacts with the out-group. Namely, the more participants supported the legitimacy of the in-group and the more importance they attached to religion, the less ready they were to engage in contacts with the out-group. Similar findings are coming from other studies as well; it was found that, in general, orthodox Jewish people have a lower tendency to support the peace plan than non-religious Jewish people (Richman \& Nolle, 2011). It means that the importance of religion in life can block a readiness to involve in contacts with an out-group. Another recent study disclosed that religious Jewish people are less supportive of the peace plan (Moore \& Aweiss, 2002); and, the less they support the peace plan, the stronger is their hate 
towards the out-group. Also, a stronger hate of the out-group was present in religious participants with a high importance for the safety issue and Jewish identity (Moore \& Aweiss, 2002).

The results of the present study coincide with ideas underlining that the admission of damage is often accompanied by a wish to redeem guilt, like asking for forgiveness, or financial compensation (Baumeister, Stillwell, \& Heatherton, 1994). This research showed, that the groups in which collective guilt was higher, did not choose cooperation strategies to a higher extent; however, collective guilt predicts a collaborative strategy and the readiness to involve in social contacts with the out-group positively, while the competing strategy is predicted negatively. Based on theoretical and practical findings, it can be stated that collective guilt facilitates a motivation to diminish the harm caused by the in-group to participants of the out-group.

The results of the present experiment supplement the range of experiments on the effect of collective guilt on conflict resolutions. The hypothesis of the study was partially proven to be true: that collective guilt predicts a collaborative strategy positively. At the same time, groups with a higher level of collective guilt supported a collaborative strategy on the same level as did groups with lower collective guilt. Baltic Jews were in general more ready for an accommodating strategy as well as more supportive of a collaborative strategy than were Israeli respondents. Respondents from Israel had higher scores in identification with Israel and in identification attachment mode. Exonerating cognitions and identification with Jewish people predicted a collaborative strategy negatively while glorification and in-group legitimacy predicted a competing strategy positively. Collective guilt predicts a collaborative strategy and a readiness to involve in social contacts with Palestinians positively and simultaneously predicts a competing strategy negatively. These results are similar to others, which showed that collective guilt positively correlates with a compromise strategy (Maoz \& McCauley, 2005).

One of the research limitations is the number of respondents, it would be interesting to take more representative random samples and extend the diversity of the sample. One of the possible future direction is to evaluate the collective guilt and other collective emotions on conflict resolutions preferences based on different distal in-groups' family ties within Israel (how many relative living in Israel etc.). It would be interesting to continue the research topic, investigating more personal and collective responsibility and guilt. Being aware of the present study's findings, several mechanisms affecting our assessment of conflicts become obvious. These findings are not limited only to the Israel-Palestine conflict; they may help us to understand other conflicts from the past, as well as other modern conflicts. By applying the findings of the present study, it becomes clear that manipulations with collective guilt can change human preferences for conflict resolutions. Especially, people with a high identification with the country (Israel) feel a necessity for updated information reflecting both in-group guilt and out-group guilt (ambiguous information) because it provides for the possibility of increasing collective guilt and reducing the perceived legitimacy of the in-group relationship. These findings can be applied in the media industry, displaying information about this conflict every day, as well as by planning common exchange programs between Jewish people and Palestinians. Since there are demographic differences, the necessity of working with people having a high identification and attaching more importance to religion is evident. It is recommended that people from different countries be included in such special training groups in order to provide them with the possibility of sharing their experience and exchanging their ideas for a better solution of this conflict.

\section{References}

Ashforth, B. E., \& Mael, F. (1989). Social identity theory and the organization. Academy of Management Review, 14, $20-39$. 
Austin, W. G., \& Worchel, S. (1979). The social psychology of intergroup relations. Monterey, C.A.: Brooks-Cole .

Bar-Tal, Y., Bar-Tal, D., \& Cohen-Hendeles, E. (2006). The influence of context and political identification on Israeli Jews' views of Palestinians. Peace and Conflict: Journal of Peace Psychology, 12(3), 229-250.

Bar-Tal, D., Chernyak-Hai, L., Schori, N., \& Gundar, A. (2009). A sense of self-perceived collective victimhood in intractable conflicts. International Review of the Red, 91(874), 229-277.

Bar-Tal, D., Halperin, E., \& Oren, N. (2010). Socio-psychological barriers to peace making: The case of the Israeli Jewish Society. Social Issues and Policy Review, 4(1), 63-109.

Baumeister, R., Stillwell, A., \& Heatherton, T. (1994). Guilt: An interpersonal approach. Psychological Bulletin, 115, 243267.

Branscombe, N. (2004). A social psychological process perspective on collective guilt. In N. R. Branscombe, \& B. Doosje (Eds.), Collective guilt: International perspectives (pp. 320-334). Cambridge: Cambridge University Press.

Branscombe, N., \& Doosje, B. (2004). Collective guilt: International perspectives. Cambridge: Cambridge University Press.

Branscombe, N., Slugoski, B., \& Kappen, D. (2004). The measurement of collective guilt: What it is and what it is not. In N. R. Branscombe, \& B. Doosje (Eds.), Collective guilt: International perspectives (pp. 16-34). Cambridge: Cambridge University Press.

Doosje, B., Branscombe, N., Spears, R., \& Manstead, A. (1998). Guilty by association: When one's group has a negative history. Journal of Personality and Social Psychology, 75(4), 872-886.

Doosje, B., \& Branscombe, N. (2003). Attributions for the negative historical actions of a group. European Journal of Social Psychology, 33, 235-248.

Doosje, B., Branscombe, N., Spears, R., \& Manstead, A. (2006). Antecedents and consequences of group-based guilt: The effects of in-group identification. Group Processes \& Intergroup Relations, 9(3), 325-338.

Halperin, E. (2008). Group-based hatred in intractable conflict in Israel. Journal of Conflict Resolution, 52, 713-736.

Halperin, E. (2011). Emotional barriers to peace: Emotions and public opinion of Jewish Israelis about the peace process in the Middle East. Peace and Conflict: Journal of Peace Psychology, 17(1), 22-45.

Halperin, E., Bar-Tal, D., Nets-Zehngut, \& Drori, E. (2008). Emotions in conflict: Correlates of fear and hope in the Israeli-Jewish society. Peace and Conflict, 14, 233-258.

Henderson, M. D. (2010). Mere physical distance and integrative agreements: When more space improves negotiation outcomes. Journal of Experimental Social Psychology, 47, 7-15.

Klein, O., Licata, L., \& Pierucci, S. (2011). Does group identification facilitate or prevent collective guilt about past misdeeds? Resolving the paradox. British Journal of Social Psychology, 50, 563-572.

Leidner, B., Castano, E., Zaiser, E., \& Giner-Sorolla, R. (2010). In-group glorification, moral disengagement, and justice in the context of collective violence. Personality and Social Psychology Bulletin, 36(8), 1115-1129.

Maoz, I. (2009). The women and peace hypothesis? The effect of opponent negotiators' gender on the evaluation of compromise solutions in the Israeli-Palestinian conflict. International Negotiation, 14, 519-536.

Maoz, I., \& Eidelson R. (2007). Psychological bases of extreme policy preferences. American Behavior Scientist, 50(11), 1476-1497.

Maoz, I., \& McCauley, R. (2005). Psychological correlates of support for compromise: A polling study of Jewish-Israeli attitudes towards solutions to the Israeli-Palestinian conflict. Political Psychology, 26, 791-807.

Maoz, I., \& McCauley, R. (2008). Threat, dehumanization, and support for retaliatory aggressive policies in asymmetric conflict. Journal of Conflict Resolution, 52, 93-116.

Moore, D., \& Aweiss, S. (2002). Hatred of "others" among Jewish, Arab, and Palestinian students in Israel. Analyses of Social Issues and Public Policy, 2(1), 151-172.

Richman, A., \& Nolle, D. B. (2011). Correlates of the Israeli public's support for a peace accord. Retrieved May 3, 2012, from http://www.worldpublicopinion.org/pipa/pdf/feb11/IsraeliPeacePlan_Feb11_rpt.pdf

Roccas, S., Klar, Y., \& Liviatan, I. (2004). Exonerating cognitions, group identification, and personal values as predictors of collective guilt among Jewish-Israelis. In N. R. Branscombe, \& B. Doosje (Eds.), Collective guilt: International perspectives (pp. 130-147). Cambridge: Cambridge University Press.

Roccas, S., Klar, Y., \& Liviatan, I. (2006). The paradox of group-based guilt: Modes of national identification, conflict vehemence, and reaction to the in-group's moral violations. Journal of Personality and Social Psychology, 91(4), 698-711.

Roccas, S., Sagiv, L., Schwartz, S., Halevy, N., \& Eidelson, R. (2008). Toward a unifying model of identification with groups: Integrating theoretical perspectives. Personality and Social Psychology Review, 12(3), 280-306. 
Sagiv, L., \& Schwartz, S. H. (1995). Value priorities and readiness for out-group social contact. Interpersonal Relations and Group Processes, 69(3), 437-448.

Schmitt, M., Branscombe, N., \& Brehm, J. (2004). Gender inequality and the intensity of men's collective guilt. In N. R. Branscombe, \& B. Doosje (Eds.), Collective guilt: International perspectives (pp. 75-95). Cambridge: Cambridge University Press.

Schori, N., Klar, Y., \& Roccas, S. (2009). When past is present: reminders of historical victimhood and their effect on intergroup conflicts. In D. Bar-Tal, E. Halperin, \& N. Oren (Eds.), Socio-psychological barriers to peace making: The case of the Israeli Jewish society (pp.63-109).

Sharvit, K., Halperin, E., \& Rosler, N. (2011). Prolonged domination: Empathy, justifying beliefs and moral emotions. Social Psychological and Personality Science-Revise and Resubmit.

Tajfel, H., \& Turner, J. (1979). An integrative theory of intergroup conflict. In W. G. Austin, \& S. Worchel (Eds.), The social psychology of intergroup relations (pp. 33-47). Monterey, C.A.: Brooks-Cole.

Trope, Y., \& Liberman, N. (2010). Construal-level theory of psychological distance. Psychological Review, 117(2), 440-463.

Wohl, M., \& Branscombe, N. (2005). Forgiveness and collective guilt assignment to historical perpetrator groups depend on level of social category inclusiveness. Journal of Personality and Social Psychology, 88, 288-303.

Wohl, M., \& Branscombe, N. (2008). Remembering historical victimization: Collective guilt for current in-group transgressions. Journal of Personality and Social Psychology, 94(6), 988-1006.

Wohl, M., Branscombe, N., \& Klar, Y. (2006). Collective guilt: Emotional reactions when one's group has done wrong or been wronged. European Review of Social Psychology, 17, 1-37. 